\title{
Board Composition, Ceo Duality and Corporate Financial Performance
}

\begin{abstract}
Iftikhar-ul-Amin ${ }^{1}$, Nadia Iftikhar ${ }^{2}$, Muhammad Yasir ${ }^{3}$
Abstract

This research study sheds light on the link between different board structure attributes and financial performance among 40 firms listed with Karachi Stock Exchange, by looking at the listing requirements which persuade greater board independence. In particular this study provides evidence that board size and sales growth positively affect corporate financial performance in Pakistan. Further according to the findings of this research there is a negative relationship of executive and non-executive (independent) directors on corporate financial performance of firms in Pakistan. Findings show that there is a mixed result shown for CEO duality and director's share holding, ROE and ROI has a positive relation with CEO duality while negative association encounters as per Tobin's q model; whereas ROE relates positively with director's share holdings while ROI and Tobin's q negatively relates to director's share holdings. The rest of corporate governance parameters e.g. internal holdings and firm size have mix relationship with financial performance.
\end{abstract}

\section{Introduction}

Board composition is a frequently research oriented topic in relation to private and public owned corporations but had less exposure with reference to Pakistan and firms listed on Karachi Stock Exchange.

A tentative answer to this statement "Whether board composition and structure affects Corporate Financial Performance?" has been indefinable. Many studies have been visited to find the answer for this very question, which are divided into two main categories. One division of these researches associates BC, BS and other attributes of board with certain performance measures (e.g. Return on Equity, Return on Investment, Tobin's $Q$ and other accounting ratios), while the rest of researches compares Board Size with shareholders' wealth and factors that affect shareholders' wealth. While this study focus on exploring events that affect CFP (Corporate Financial Performance) on the basis of ROE, ROI and Tobin's $Q$.

Board of directors cannot serve efficiently and effectively if they do not have the "right people" as members and the "right chairman" as leader. Moreover, should also be aided by "right" attitudes on the part of management, the external auditor and other advisors.

1 Assistant Professor, Institute of Management Sciences Peshawar

2 Assistant Professor, Institute of Management Sciences Peshawar

3 Research Student, Institute of Management Sciences Peshawar 
Corporate Governance is the overall procedure of running affairs and dealings of business entity, that are directed towards ultimate objective of maximizing shareholders' wealth through increased profits which can be achieved by enhancing corporate responsibility among board members. One core element that can improve overall economic efficiency is exercising corporate governance in its true spirit, which can be achieved through strong bonding of BOD (Board of Directors), companies management and its internal and external stakeholders. Since objectives and goals of a company may be set through corporate governance, which provides the incentive of achieving and fulfilling those objectives, and financial performance may be measured.

Running corporate governance process efficiently and effectively manages financial resources, strengthens the company and provides sound footings to the economy, which as a result enhances confidence of the domestic and foreign investors by offering lower cost capital investment. Good corporate governance increases responsibility and liability of BOD and management. The Board of directors will also ensure legal observance and take unbiased decisions for the betterment of the business entity. It is also studied that corporations where corporate governance is strictly practiced, fraudulent activities are hard to come by in those firms. There are number of aspects that can affect corporate governance and decision making within a firm. And the main focus is to minimize corporate governance evils, because it results in dispute among parties, which adversely affect company's growth.

The developed nations of the world like UK, Germany, USA, Hong Kong etc have introduced different models for corporate governance which are now being applied there in true spirit. The World Bank also expressed keen attention to this issue and developed World Governance Index (WGI). The reason for which World Bank developed this index is to judge corporate performance of various countries on the basis of Rules and Regulations and the level of corruption prevalent over there. The results of the index showed that the leading performer in corporate governance is Germany with a score of $90.8 \%$ and the worst performer is Bangladesh with a score of 24.3.

As the status of the Pakistan's economy in 2011, stressed as it is; the financial and administrative turn-around put national economy on back-foot. Preferably it would be more advantageous to take a look at the governance issues at macro level for Pakistan. However, focus of this study is to examine the governance issues for the non-financial sector of Pakistan and to find-out the relationship of the BS, ED, NED, DH, IH and CEO duality with corporate financial performance, of the companies listed with KSE. According to an economist, (Javaid. S, 2010) a keen observer of economy of Pakistan lately stated that "Pakistan has the capability of generating greater rebounds in its economy than India by enhancing governance. It has happened before in the country's tricky economic history and could occur again." 


\section{Literature Review}

Literature review for this research study comprises of four segments which is divided according to the research questions and requirements of this study.

\subsection{Size Of Board And Corporate Financial Performance}

Board Size is the most important component of Board Structure. Researchers given variety of opinions as per their findings, some researches argues that boards comprises of more than average directors performs better and help company to gain competitive edge and eliminate externalities that affect company negatively, (Pearce and Zahra 1992); (Goodstein et al 1994). In contrast to these researches Yermack (1996) argues that communication and coordination decreases and decision making adversely affect when Directors are large in number. On the other side Jensen (1993); Lipton and Lorsch (1992) presents the point that BS should be between seven and eight members. However, it is also seen that BS (Board Size) varies from industry to industry. Adams and Mehran (2003) have showed that manufacturing companies have significantly smaller boards than those of banking companies.

Empirical studies on impact of Board Size on Corporate Performance showed relatively mixed results. Dehaene et al (2001) finds that BS (Board Size) positively affects CP (Corporate Performance). Results also differ when different performance measures are used, market performance measure suggesting that, with larger board performance become less effective, but this result is contradictory when accounting performance measure e.g. ROE, ROI or profitability ratios are used performance become aggressive, which illustrates that larger boards provide companies with diversity of expertise and experience required to apprehend financial performance.

There is an inverse relation exist between board size and firm value (Yermack 1996), in addition to this with increasing BS (board size) there is a declining effect showed in operating efficiency and profitability ratios. Since, according to Connelly and Limpaphayom (2004) there is no association exists between BS (board size) and CP (corporate performance).

Prior studies on group decision making reveal that generally it is harder for larger groups to reach an agreement. Thus, for supervisory boards it is generally assumed that smaller boards are more effective at monitoring due to lower co-ordination costs and therefore result in a better Performance; this is confirmed by (Yermack 1996). This view is not shared by all researchers though, as Dalton et al (1999); Coles et al (2008) argue that larger boards may be better for firms with greater advising requirements (e.g. for complex firms that operate in multiple segments). Added to this Raheja (2005) argues, that "optimal BS (board size) and BC (board composition) are the functions 
of BOD and ultimately affects CP (corporate performance).

To bridge the gap between BS (board size) and CFP (Corporate Financial Performance) a test of efficiency and effectiveness of the board is mandatory; while research finds mixed results on the effectiveness of firm's boards in the US. Morck et al (1989) shows that German corporate boards are effective in replacing poor performer of management board when required.

\subsection{Composition Of Board And Corporate Financial Performance}

This section summarizes articles related to board composition. Board Composition means percentage of the Non-Executive Directors in the BOD relative to total members of the board. NED (Non-Executive Directors) is also termed as Independent Directors; a NED is a director who does not have any stake in company affairs except for his/ her directorship (Clifford and Evans 1997). There is a general conception that the board which is largely shaded by ID will perform better with better decision making as compared to boards of ED dominancy.

According to Fama and Jensen (1983) NED dominated board minimizes agency problems that result in efficient decision making and organization prosper quickly. However, multiple of researches are conducted for this purpose, those empirical studies showed conjunction in results, there is a positive impact showed on CP, credit ratings and stock returns with Non-Executive Directors dominancy, because NED have been effectively protecting shareholder's interest and monitoring managers.

Independent Directors positively relates to Corporate Performance of firms in Belgium (Dehaene et al 2001). Further Connelly and Limpaphayom (2004) argue that $\mathrm{BC}$ positively relates with profitability.

Agrawal and Knoeber (1996); Yermack (1996) finds that board composition negatively effects CFP with Tobin's Q, while Vafeas and Theodorou (1998) shows no significant association of percentage of NED with accounting performance measures. Furthermore, one other research for the same issue, Hooghiemstra and van Manen (2004) have concluded that NED generally not able to satisfy stakeholders.

Corporate governance mechanism cannot be run without the help of Board members; hence they are expected to play a critical part in monitoring corporate managers and for smooth running of other related affairs. Since, it is examined that boards with NED dominancy are better controlled and monitored. However, as per the findings of Agarwal and Knoeber (1996) no solid reason is found to believe that higher proportion of NED affect CP. 
Since, ownership structure and board characteristics are associated with each other. Agarwal and Knoeber (1996) find function among different corporate mechanisms, and argue that they are interdependent.

\subsection{Ownership Of Firm And Corporate Financial Performance}

Board Ownership is the essence of Board Structure, because it reduces conflict of ownership among Executive and Non-Executive Directors of board and managers of a firm. If ED own part of firm or having ownership stake in firm, there is less probability that they will indulge in misdeed which are injurious to shareholder's interest. However, IH negatively related to conflicts of shareholders and managers.

In contradiction to this opinion, Demsetz and Lehn (1985) suggested that there is no relationship between OS and FP, and concluded that probability of conflict is little between shareholder and manager. Whereas McConnell and Servaes (1990) suggesting a significant relationship between Insider Holdings and Tobin's Q, this study further states that Tobin's $Q$ increases up-to certain limit but after that FP starts to decline because of concentrated ownership of $\mathrm{IH}$, possible reason for this type of result could be that ED and managers become more self oriented as percentage of ownership increases with them.

There is difference in profitability occurs as per difference in Ownership Structure. Leech and Leahy (1991) find that profitability is marginal in diversified owned companies, while profitability is high in concentrated owned firms.

Researches conducted in this area around the world concluded that there will be more market capitalization on those stock markets where investor's interest is well sheltered. Possible reason of positive impact on profitability in case of diverse ownership is that minimum IH (independent directors) may disable ED (executive directors) and management to give priority to own interest.

On the other hand empirical results showed that identification of investor group in corporate governance is also important, whether scattered or diversified. Investor may be a corporation, individual, family or financial institution, based on their investment patterns their objectives also vary. For example, individual block-holders mostly monitor events affecting firm's profitability very closely and this involvement can significantly boost firm performance.

There are many researches done in this area, but mostly for developed economies where, stock markets are active and rich data is available. Pakistan market is distinct to that of those countries because in Pakistan there is large pool of family owned corporations. 


\subsection{Ceo Duality And Corporate Financial Performance}

Priority-wise CEO is the most important individual of a company, who is the final authority as far as decision making and strategy formulation is concern. CEO duality means performing two jobs by one individual, by taking the additional responsibility of heading the Board of Directors. There are two schools of thought on CEO duality that give varying opinions on this characteristic of Board Structure.

One section of those researcher find-out arguments in favor of CEO duality while others discourages this dual role. Fama and Jensen (1983); Rechner and Dalton (1991) gives arguments against to this point, according to them chairperson may assist CEO on critical corporate issues and help in decision making process, so far this vary reason $\mathrm{CEO}$ and chairperson should be separate individuals.

Contradictory to this, other scholars believed that through CEO Duality, the same person performing dual role may give rise to efficiency within an organization through unity of command and this duality will be helpful in eliminating conflict of opinion between chairperson and CEO (Donaldson and Davis 1991). Agreeing to this conclusion Cannella and Lubatkin (1993) find a positive relationship between CEO duality and Corporate Financial Performance; while Brickley et al (1997) find a negative relationship of financial performance with market measure Tobin's $Q$.

The supporters of the CEO duality tell that the CEO duality may be required when such duality might enhance corporate performance (Tricker 1994) and the firm requires strong leadership (Finkelstein and Hambrick 1996). CEO duality has several advantages, such as it places the $\mathrm{CEO}$ in a powerful position in managing the firms operations and enables to make quick decision (Finkelstein and Hambrick 1996)

\section{RESEARCH METHODOLOGY AND DESIGN}

\section{Research Question}

The Board of Directors of listed companies often have been criticized by the shareholders' for not maximizing company value, which in turn affects stock returns and shareholders' wealth negatively. Directors have been subject to fraudulent activities which ultimately resulted in corporate failure. For this very reason Corporate Governance Reforms have been introduced for making appropriate changes to board structure in terms of BS (board size), percentage of ED (executive directors), NED (non-executive directors)and DH (directors holding). Therefore, this study extends and contributes to the body of research using Pakistani data to research the relationship between Board Structure and CFP (Corporate Financial Performance). Findings of this study would be useful to the stakeholders of KSE, as it provides strong proof of asso- 
ciation of Board Size, and Board Composition on Corporate Financial Performance.

This research serves multiplicity of purposes i.e. the core purpose is to implement Corporate Governance in a manner which refers to the pattern an organization is intended for, administered or controlled. It includes the set of rules and regulations that influence the manager's decision and contributes the way a company is perceived by the current and potential stakeholders. Corporate governance gives directions of rights, liabilities and responsibility for every individual associated with corporate setup of an organization, e.g. BOD, middle and lower level management, administration, shareholders and other stakeholders, who also assist in decision making process of corporate dealings. By applying the process of corporate governance structure, that provides means of setting and achieving goals and objectives. In short, corporate governance is the pattern through which interest of diverse investors and managers may be brought upon a single opinion and ensure that company affairs are proceeding in direction as investors have phrase. This research is specifically designed to meet the following objectives:

(a) To assess the extent up-to which Board Size affects Corporate Financial Performance of firms in Pakistan?

(b) To examine relationship between the Non-Executive Directors and Corporate Financial Performance of firms in Pakistan.

(c) To measure the impact of the Directors Holdings on Corporate Financial Performance of firms in Pakistan.

(d) To identify the relationship between CEO duality and Corporate Financial Performance of firms in Pakistan.

The study attempts to find answers to the following specific questions based on objectives stated for this study.

Q No. 1: Is there any relationship between board size and corporate financial performance?

Q No. 2: Does the number of independent / outside directors have any relationship with corporate financial performance of a firm in Pakistan?

Q No. 3: What effect does directors share holdings have on corporate financial performance in Pakistan?

Q No. 4: Is there any association between CEO duality and corporate financial performance in Pakistan? 


\section{Methodology}

This study is quantitative in nature. The methodology adopted for this study is illustrated in this chapter. For analysis of this study three dependent and few independent variables are introduced as proxy for financial performance and board structure characteristics. And to elaborate the relationship between Board Composition, Board Structure and Financial Performance of a company; sample size is 40 non financial listed companies of KSE. This study uses 40 companies "Annual Reports" of five years from (2006-2010) as its dataset. Non-probability convenience sampling technique is used for this study. The software used for this research study is GRETL, and panel data regression model is applied as a technique and on the basis of its output; analysis and interpretation is done.

Board composition measures include the percentage of Executive and Non-Executive Directors of board as compared to entire BOD and other related independent variables are taken as proxy for board size and structure e.g. CEO dummy, IH, DH, SG and FS. Firm performance is represented by three performance measure standards the accounting ratios and market performance indicator e.g. ROI, ROE, and Tobin's Q.

\subsection{Sampling Technique}

Selection of data in quantitative research is a critical and important part of research from researcher point of view. The sampling technique used for this study is non-probability convenience sampling, as data was not easily available.

\subsection{Data And Sample}

The sample of 40 listed companies is selected for this research study, which represents non-financial sector. Companies cover up to some extent the market capitalization and are listed on KSE. The data used for this study is secondary in nature.

\subsection{Sources Of Data}

The data required for this research was not fully available in published form, except for firm annual reports and on certain occasion's only financial statements available with KSE and on company's official website is used.

Since this is a quantitative study; so for this research data is collected from available Annual Reports of 40 non-financial listed companies with KSE for the years 2006-2010.

\subsection{VARIABLES}

Following dependent and independent variables are introduced for this research 
study in-order to come with meaningful consequences.

\subsubsection{Dependent Variables}

FINANCIAL PERFORM = performance measure taken as $(\mathrm{ROI}, \mathrm{ROE}$, and Tobin's Q).

(1) ROI: (return on investment); and calculated through following formula:

EAT/ B.V of total assets (\%)

(2) ROE: (return on equity); and calculated through following formula:

EAT/ Equity or (Net-worth) (\%)

(3) Q: (Tobin's Q/ Q Ratio); and calculated through following formula:

Total market value of firm / B.V of total assets (\%)

Where Total M.V of firm= (no. of shares * average share price)

\subsubsection{Independent Variables}

Following are the proxies introduced for Board Structure characteristics.

(a) $\mathrm{BS}=$ Board size, total number of board members.

(b) $\mathrm{ED}=$ Percentage of executive directors in board.

(c) $\mathrm{NED}=$ Percentage of non-executive / independent directors in board .

(d) $\mathrm{IH}=$ Inside holdings, percentage of net-worth owned by insiders.

(e) $\mathrm{DH}=$ Directors Holdings, Proportion of share holdings owned by executive and non- executive directors.

(f) $\mathrm{CEO}=\mathrm{CEO}$ dummy, Equals to 0 if $\mathrm{CEO}$ perform dual role, 1 otherwise.

(g) $\mathrm{SG}=$ Sales Growth, percentage of growth in sales compared to last year.

(h) FS= Firm size, BV of total assets, $\log 10$ is taken for analysis.

\subsection{Regression Models}

Based on variables and requirement of research, there are three regression models run for analysis in this study. 
(1) Regression Model for ROE

(2) Regression Model for ROI

(3) Regression Model for Tobin's Q

\subsection{Statistical Analysis}

Based on the dependent and independent variables stated earlier following regression equations are derived for Fixed and Random Effect panel data regression model. These are developed to test the relationship for analysis and estimation between the dependent and independent variables of this research study:

$>$ Equation for Fixed Effect Model

Financial Performance $(P)=A 0+\alpha 2006+\alpha 2007+\alpha 2008+\alpha 2009+\alpha 2010+$ $\beta 1 \mathrm{BS}+\beta 2 \mathrm{ED}+\beta 3 \mathrm{NED}+\beta 4 \mathrm{IH}+\beta 5 \mathrm{DH}+\beta 6 \mathrm{CEO}+\beta 7 \mathrm{SG}+\beta 8 \mathrm{FS}+e 0$

$>$ Equation for Random Effect Model

Financial Performance $(P)=\alpha 0+\beta 1 B S+\beta 2 E D+\beta 3 N E D+\beta 4 I H+\beta 5 D H+\beta 6 C E O$ $+\beta 7 \mathrm{SG}+\beta 8 \mathrm{FS}+e 0$

\section{Analysis Of The Data}

This chapter of the research is dedicated to presenting the results of the analysis executed on the data collected to test the scheme made in the research and answer the research questions. Analyses were carried out with the help of the "GNU Regression, Econometric and Time-series Library" (GRETL Version 1.9.5). In GRETL cross-sectional panel data regression model is applied for this research study which include 40 cross-sectional units (companies) for 5 years (Time-series length is 5), in totality 200 observations. There are two types of panel data regression models; (1) Fixed- effect model and (2) Random- effect model, Fixed- effect model is better off in that case where Hausman test $\mathrm{P}$ - value is below or equal to $5 \%$ or 0.05 and whereas in alternative scenario in which Hausman test $\mathrm{P}$-value is above $5 \%$ or 0.05 , Randomeffect model is used. In this research Fixed- effect model is used for ROE and ROI analysis, whereas Random-effect model is used for Tobin's $Q$ analysis.

\subsection{Empirical Results And Findings}

Basically for this research study three panel data regressions are executed to verify different aspects of corporate financial performance e.g. ROE, ROI and Tobin's $q$ and each one is illustrated by showing descriptive statistics and effect of that particular ratio on company's financial performance. 


\section{Discussion}

As per the findings of this research there is a positive and statistically significant relation exists with ROE, ROI and Tobin's $Q$ between BS and CFP in Pakistan. Since larger Boards provides diversity and competitive edge to companies as it is found in this study that average board size is approx nine. Further, operating efficiency and

Table 1: Frequency of Determinants

\begin{tabular}{|c|c|c|c|c|}
\hline & Minimum & Maximum & Mean & Std. Deviation \\
\hline ROE & -174.30 & 137.20 & 13.0648 & 30.28764 \\
\hline ROI & -38.20 & 55.60 & 7.0554 & 12.50343 \\
\hline TQ & .00 & 511.88 & 64.9953 & 65.94649 \\
\hline BS & 7.00 & 15.00 & 8.9150 & 2.44698 \\
\hline NED & .00 & 13.00 & 2.8400 & 3.75699 \\
\hline IH & .00 & 95.02 & 33.3938 & 26.26186 \\
\hline DH & .00 & 74.00 & 12.0479 & 18.32146 \\
\hline CEO & .00 & 1.00 & .8650 & .34258 \\
\hline FS & 8.80 & 12.36 & 10.3077 & .64814 \\
\hline SG & -96.71 & 99.01 & 17.7390 & 26.60863 \\
\hline
\end{tabular}

profitability ratios also showed increasing trend with larger boards. The findings are consistent with that of Dehaene et al (2001).

As per the findings of this research there is a negative relationship showed with Tobin's $Q$ between NED and CFP of a firm in Pakistan, the findings is identical to that of (Agrawal and Knoeber 1996); (Yermack 1996). These findings are contradictory to (Dehaene et al 2001) and (Connelly and Limpaphayom 2004), because most of the companies of Pakistan are family owned and discourage outside dominancy. More reasons could be that high proportion of NED can affect company in unnecessary supervision, which may be injurious to companies and to shareholder's interest and companies in Pakistan also do not follow Corporate Governance Code Act in its true spirit.

According to the findings of this research there exists a mixed finding on this aspect of research as shown by descriptive statistics, $\mathrm{DH}$ relates positively to ROE which is also consistent to (Morck et al 1988), whereas directors share holdings negatively relates to ROI and Tobin's q, which is identical to (Lehman and Weigand 


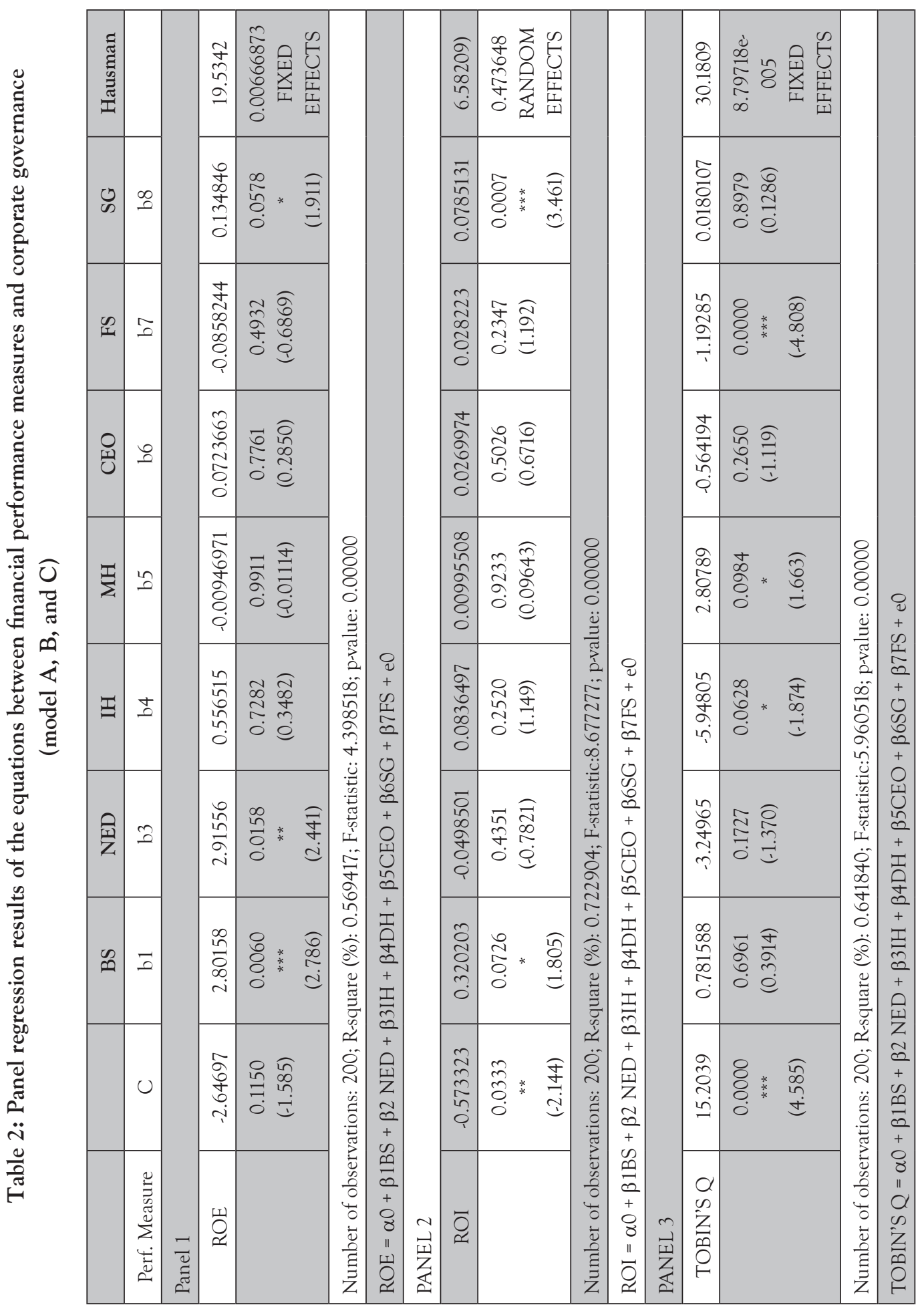


2000) findings, which ultimately affect CFP of a firm in Pakistan.

According to the findings of this research there exists a mixed result to this aspect of research as shown by descriptive statistics. ROE and ROI positively associated with CEO duality, Consistent with these arguments, (Cannella and Lubatkin 1993) report a positive link between $\mathrm{CEO}$ duality and financial performance and negative association occurs as per Tobin's q model, same to (Brickley et al 1997) findings. Positive relation exists because scholars believed that through CEO Duality the same person performing dual role may give rise to efficiency within an organization through unity of command and this duality will be helpful in eliminating conflict of opinion between chairperson and CEO (Donaldson and Davis 1991).

\section{Conclusion}

Corporate governance is a very important issue as for as companies internal affairs are concerned. It is vastly research oriented topic in many countries of the world but less research has been done with reference to Pakistan. The need arises for strengthening corporate structure is due to large corporate failure in listed companies around the world e.g. WorldCom, Enron, One-Tel, Ansett etc. The reason behind choosing this topic was to find whether or not various characteristics of board exercising in its true spirit in listed companies of Pakistan. Pakistan market is distinct to that of developed countries because in Pakistan there is large pool of family owned corporations while outside dominancy is discouraged.

The relationship of variables of corporate governance has been widely researched but very few variables have been taken. In this research study a large number of corporate governance variables are taken \& their relationship is found with three elements of financial performance e.g. ROE, ROI and Tobin's q.

In the radiance of the above mentioned conclusion, it would not be wrong to say that relationship between corporate governance characteristics and performance measures standards of this study find varied results.

Corporate governance importance cannot be over-looked both within organizational perspective and outside stakeholder's perspective; and from point of view of prospect investor's. Implementing corporate governance practices ensure smooth running of business entity by boosting profitability and enhancing decision making in long-run especially for companies in Pakistan and achieving market dominancy through competitive edge.

As observed ideal board size would be nine directors comprises of a board, with four non-executive (independent) directors and remaining executive directors and 
chairperson and CEO being separate individuals. Director's share holdings are helpful to eradicate dispute among diverse stakeholders.

Ideally there are quiet large numbers of factors that independently affect corporate performance are economic, social, legal, socio-economic, political and technological environment. This study is confines to its domain and future prospect will be to take a broader view.

As a concluding remark this would be better of mentioning that this study is still in its embryonic phase and attempt is made with limited data in order to find some meaningful outcome. It would be likely to expand this research study and use panel data for more than five years to come out with better findings. Thus, successive to this research next step will be to explore the financial services sector, banking sector and non-financial sector in more depth

\section{References}

Adams, R., \& Mehran, H. (2003), "Is Corporate Governance Different for Bank Holding Companies"? Economic Policy Review, 9, 123-142.

Agrawal, A., \& Knoeber, C. (1996), "Firm performance and mechanisms to control Agency problems between managers and shareholders”. Journal of Financial Quantitative Analysis, 31, 3, 377-397.

Brickley, J. A., Coles, J. L., \& Jarrell, G. (1997), "Leadership structure: Separating the CEO and Chairman of the Board". Journal of Corporate Finance, 3, 189-220.

Bolton, P. and E. von Thadden (1998), "Blocks, Liquidity and Corporate Control”, Journal of Finance, vol. $53,1-25$

Cannella, A. A., \& Lubatkin, M. (1993), "Succession as a socio-political process: Internal impediments to outsider selection”. Academy of Management Journal, 36, 4, 763-793.

Clifford, P., \& Evans, R. (1997), "Non- Executive Directors: A Question of independence". Corporate Governance, 5, 4, 224-231.

Coles, J.; N. Daniel; L. Naveen (2008), "Boards: Does One Size Fit All”? Journal of Financial Economics, 87 (3): 329-356.

Connelly, J. T., \& Limpaphayom, P. (2004), "Environmental reporting and firm performance: evidence from Thailand". The Journal of Corporate Citizenship, 13, 1, 37149

Dalton, D. R. and C. M. Daily (1999), "What's Wrong With Having Friends on the Board, Across the Board"? Journal of Financial Economics, 36 (3): 28-32.

Dehaene, A., De Vuyst, V. and Ooghe, H. (2001), "Corporate Performance and Board Structure in Belgian Companies. Long Range Planning”. Journal of Financial Economics 34, 3, 383-398 
Demsetz, H. and K. Lehn (1985), "The Structure of Corporate Ownership: Causes and Consequences”. Journal of Political Economy, vol. 93, 1155-1177.

Donaldson, L. and J. H. Davis (1991), "Stewardship Theory or Agency Theory: CEO Governance and Shareholder Returns”. Australian Journal of Management, 16 (1): 49-69,

Fama, E., \& Jensen, M. (1983), "Separation of Ownership and Control”. Journal of Law and Economics, 26, 301-325.

Finkelstein, S. and D. C. Hambrick (1996), "Strategic Leadership: Top Executives and Their Effects on Organization”. West Publishing Company, Minneapolis/St. Paul.

Javaid, S. (2010, 12 oct). "Improved Governance”: Dawn. p. 13

Jensen, M.C. (1993), "The Modern Industrial Revolution, Exit, and the Failure of Internal Control Systems". Journal of Finance, 48, 3, 831-880.

Leech, D., \& Leahy, H. (1991), "Ownership structure, control type classifications, and the performance of large British companies”. Economic Journal, 101, 409, 1418-1437.

Lipton, M. \&. Lorch, J. W. (1992), "A Modest Proposal for improved Corporate Governance”. The Business Lawyer, 48, 1, 59-77.

McConnell, J., \& Servaes, H. (1990), “Additional evidence on equity ownership and Corporate value". Journal of Financial Economics, 27, 2, 595-612.

Pearce, H., \& Zahra, S. A. (1992), "Board Composition from a Strategic Contingency Perspective". Journal of Management Studies, 29, 411- 438.

Raheja, C. (2005), "Determinants of Board Size and Composition: A Theory of Corporate Boards". Journal of Financial and Quantitative Analysis, 40 (2): 283-306.

Rechner, P., \& Dalton, R. (1991), “CEO duality and organizational performance: A longitudinal analysis”. Strategic Management Journal, 12, 2, 155-160.

Shleifer, A., \& Vishny, R. (1988), “Management ownership and market Valuation”. Journal of Financial Economics, 20, 1/2, 293-315.

Vafeas, N., \& Theodorou, E. (1998), “The Relationship between Board Structure and Firm Performance in the UK”. British Accounting Review, 30, 4, 383-407.

Yermack, D. (1996), "Higher market valuation of companies with a small board of directors". Journal of Financial Economics, 40, 2, 185-211. 
